\title{
ANALISIS KEBUTUHAN PEGAWAI DI SEKRETARIAT DAERAH KABUPATEN MAROS
}

\author{
Marlina \\ Alumni Program Magister Pascasarjana UNM \\ Dahyar Daraba \\ Dosen IPDN Kampus Sulawesi Selatan \\ H. M. Said Saggaf \\ Dosen STIA PRIMA, Sengkang
}

\begin{abstract}
ABSTRAK
Penelitian ini bertujuan untuk mengetahui analisis kebutuhan pegawai di Setda Kabupaten Maros. Penelitian ini adalah deskriptif kualitatif yang bertujuan untuk memberikan gambaran tentang permasalahan yang diteliti/dikaji. Teknik yang digunakan dalam pengumpulan data melalui observasi, studi dokumentasi dan wawancara terbuka, sedangkan pengolahan data dan analisis data dilakukan dengan teknik analisis data kualitatif, yakni: (1) reduksi data, (2) penyajian data, dan (3) kesimpulan dan verifikasi.Hasil penelitian menunjukkan bahwa analisis kebutuhan pegawai Setda Kabupaten Maros dimulai dari penetapan tugas pokok, fungsi dan uraian jabatan/pekerjaan sebagai tahap awal. Tahap kedua yaitu analisis jabatan, Tahap yang ketiga yaitu analisis beban kerja yang diperoleh perhitungan kebutuhan pegawai untuk tiap jabatan staff. Hasil penelitian juga menunjukkan bahwa secara umum Sekretariat Daerah Kabupaten Maros jika dilihat dari Kebutuhan berdasarkan ABK masih membutuhkan pegawai sebanyak 11 pegawai dari 185 pegawai yang ada. Meskipun demikian, berdasarkan kebutuhan pegawai melalui $\mathrm{ABK}$ terjadi kelebihan pegawai dibeberapa bagian dan kekurangan pegawai dibeberapa bagian dalam Sekretariat Daerah Kabupaten Maros sehingga hal inimerupakan salah satu faktor yang menyebabkan tidak tercapainya efektivitas kerja pegawai karena ada beberapa pegawai yang tidak bekerja sementara ada sebagian pegawai kelebihan pekerjaan.
\end{abstract}

Kata Kunci: analisis kebutuhan pegawai, analsis beban kerja

\section{PENDAHULUAN}

Undang-Undang (UU) No 43 tahun 1999 tentang perubahan atas UU No 8 Tahun 1974 tentang pokok-pokok kepegawaian mengamanatkan bahwa setiap organisasi pemerintah pusat maupun daerah dituntut untuk memiliki Sumber Daya Manusia Pegawai Negeri Sipil (PNS) yang memenuhi persyaratan baik kualitas maupun kuantitas, sehingga dapat melaksanakan tugas dan fungsi secara profesional. Kualitas SDM-PNS yang antara lain ditentukan oleh rekrutmen yang merupakan proses aktivitas mencari dan menentukan SDM-PNS yang memiliki pengetahuan (Knowledge), Keterampilan (Skill) dan Sikap (Attitude) yang diperlukan dalam melaksanakan tugas pekerjaannya.

Motor penggerak utama organisasi adalah manusia sehingga organisai yang memiliki produktivitas dan efektivitas kinerja yang baik lahir dari oragnisasi yang memiliki dukungan 
Marlina, Dahyar Daraba dan H. M. Said Saggaf, Analisis Kebutuhan Pegawai |17

SDM aparatur organisasi yang baik. Terkait dengan adanya dukungan manusia yang berkualitas berarti dibutuhkan adanya SDM Pegawai Negeri Sipil yang memiliki spesialisasi-spesialisasi keahlian yang menunjang kinerja organisasi yang kemaudian diatur, dikelola, dan diarahkan untuk mengembangkan potensinya.

Pengadaan atau rekrutmen merupakan komponen manajemen SDM yang secara normatif telah diatur dalam peraturan pemerintah (PP) No. 97 tahun 2000 tentang formasi PNS sebagaimana telah diubah dengan PP No 54 Tahun 2003 dan PP No 98 Tahun 2000 sebagaimana telah diubah dengan PP No 11 Tahun2002 tentang pengadaan PNS. Di dalam peraturan PNS, rekrutmen diistilahkan dengan pengadaan PNS. Pengadaan PNS merupakan kegiatan untuk mengisi formasi yang lowong, oleh karena itu pengadaan harus dilaksanakan atas dasar kebutuhan baik dalam arti jumlah dan mutu pegawai maupun kompetensi jabatan yang dibutuhkan. Namun gambaran manajemen SDM pada organisasi pemerintah saat ini masih carut marut. Dapat terlihat dalam sebuah Satuan Kerja Perangkat Daerah, jumlah pegawainya tidak proporsional karena tidak teraturnya atau tidak terdistribusinya pegawai berdasarkan kompetensi yang dimiliki serta jenis pekerjaan yang ditugaskan padanya.

Pengadaan Sumber Daya Manusia PNS tidak serta merta begitu saja, akan tetapi harus melalui analisis kebutuhan pegawai sehingga dengan cermat dapat diperoleh jumlah pegawai yang dibutuhkan berdasarkan hasil perhitungan beban kerja dan analisis pekerjaan sehingga dapat memperoleh pegawai yang diharapkan kompeten untuk menempati jabatannya. Dalam hal ini analisis kebutuhan pegawai pada suatu organisasi diharapkan dapat meningkatkan efektivitas kerja pada organisasi tersebut. Sekretariat daerah Kabupaten Maros mempunyai tugas membantu bupati dalam melaksanakan tugas pokok penyelenggaraan pemerintahan, adminnistrasi organisasi, dan tata laksana serta memberikan pelayanan administratif kepada seluruh perangkat daerah.

\section{KAJIAN TEORI}

Analisis kebutuhan pegawai merupakan bagian dari pengadaan (procurement). Menurut Hasibuan (2001:27) pengadaan (procurement) adalah fungsi operasional pertama MSDM. Lebih lanjut dikatakan bahwa pengadaan karyawan meruapakan masalah penting, sulit, dan kompleks karena untuk mendapatkan dan menempatkan orang-orang yang kompeten, serasi, serta efektif tidaklah semudah membeli dan menempatkan mesin. Pengadaan adalah salah satu fungsi Manajemen Sumber Daya Manusia, sehingga dalam mendiskusikan konsep analisis kebutuhan pegawai tidak terlepas dari pembahasan masalah Sumber Daya Manusia yang merupakan unsur terpenting dalam organisasi. Samsuddin (2006:22) mengemukakan bahwa "manajemen sumber daya manusia (human resources management) adalah suatu kegiatan pengelolaan yang meliputi pendayagunaan, pengembangan, penilaian, pemberian balas jasa bagi manusia sebagai individu anggota organisasi".

Yuniarsih \& Suwanto (2008:3) mengemukakan bahwa "manajemen sumber daya manusia adalah serangkaian kegiatan pengelolaan sumber daya manusia yang memusatkan kepada praktek dan kebijakan, serta fungsi-fungsi manajemen untuk mencapai tujuan organisasi”. 
Berdasarkan beberapa pendapat ini maka manajemen sumber daya manusia adalah menyangkut cara-cara mendesain perencanaan, penyusunan karyawan, pengelolaan karier, evaluasi kinerja, kompensasi karyawan dan hubungan ketenagakerjaan.

\section{Kebutuhan Pegawai}

Upaya membantu organisasi mencapai tujuannya, diperlukan sumber daya manusia yang tepat, yang memiliki kemampuan sesuai dengan beban tugas yang harus dilaksanakan supaya tugasnya dilaksanakan secara efektif dan efisien. Menurut Martoyo (2000: 21) "pengadaan tenaga kerja yang tepat untuk memperoleh jumlah dan jenis tenaga kerja yang tepat untuk memenuhi kebutuhan tenaga kerja yang dibutuhkan guna mencapai tujuan organisasi”. Oleh sebab perencanaan Sumber Daya Manusia sangat berperan terhadap kebutuhan dan suplai pegawai di masa yang akan datang.

Setiap organisasi baik pemerintah maupun swasta harus memiliki kemampuan dalam memprediksi kebutuhan pegawai, dalam konteks ini tentu tidak hanya berkaitan dengan kuantitas, akan tetapi juga kualitas SDM yang diperlukan. Namun, perencanaan sumber daya manusia atau pegawai dapat dilakukan jika jelas sebab atau alasan perlunya menambah jumlah SDM/pegawai. Sedarmayanti (2010: 107-108), memberi rincian penyebab tuntutan permintaan SDM masa depan :

1. Tantangan Eksternal

a. Bidang ekonomi: tingkat inflasi, pengangguran, perubahan pola kemampuan kerja, tingkat bunga mempengaruhi bisnis.

b. Sosial, politik, hukum, perubahan aturan, sikap dan tingkah laku.

c. Teknologi dan gejolak sumber daya manusia, robot.

d. Persaingan dan pembajakan pimpinan harus disiapkan gantinya

2. Keputusan Organisasi

a. Rencana strategis: pertumbuhan, produk atau segmen pasar baru.

b. Anggaran.

c. Ramalan penjualan dan produksi.

d. Usaha baru atau peluang bisnis baru atau perluasan usaha.

e. Desain organisasi dan kerja.

3. Kapasitas Kerja

a. Pensiun.

b. Pengunduran diri.

c. Pemberhentian setelah kontrak selesai.

d. Kematian.

e. Cuti.

f. Menaikkan kebutuhan karyawan

Pendapat ahli di atas mengenai penyebab tuntutan permintaan SDM atau pegawai masa depan adalah berorientasi pada organisasi profit, sedangkan untuk organisasi non profit yang berorientasi pada pelayanan dan pemberi jasa seperti instansi pemerintah, penyebab tuntutan 
permintaan SDM/pegawai dapat disesuaikan dengan keadaan atau kondisi terkait. Salah satu faktor penyebab tuntutan permintaan SDM adalah faktor ketenagakerjaan itu sendiri. Sebagaimana yang dikemukakan oleh Nawawi (2008:171) mengenai faktor ketenagakerjaan "faktor ini adalah kondisi tenaga kerja (SDM) yang dimiliki perusahaan sekarang dan prediksinya di masa depan yang berpengaruh pada permintaan (demand) tenaga kerja baru".

\section{Analisis Jabatan}

Formasi pegawai harus dapat ditunjukkan dengan jumlah pegawai dalam jabatan. Maksudnya adalah agar setiap pegawai yang menjadi bagian dalam formasi memiliki kedudukan dalam jabatan yang jelas. Dengan demikian, sebelum dilakukan perhitungan formasi terlebih dahulu harus tersedia peta jabatan dan uraian jabatan yang tertata rapi. Menteri Pendayagunaan Aparatur Negara (2004) menyatakan Peta jabatan dan uraian jabatan diperoleh dengan melakukan analisis jabatan. Oleh karenanya, analisis jabatan merupakan tahap awal dalam pelaksanaan perhitungan formasi. Dari beberapa pengertian mengenai analisis jabatan ataupun analisis pekerjaan berikut, kata jabatan dan pekerjaan digunakan bersamaan pada dasarnya bermaksud untuk menghindari persepsi yang sempit atau terbatas dalam melaksanakan analisis jabatan atau pekerjaan sebagai salah satu kegiatan manajemen sumber daya manusia.

Perkataan jabatan dimaksudkan bahwa analisis dapat dilakukan terhadap unit kerja seperti departemen, divisi, bagian, dalam struktur organisasi sebuah organisasi. Dengan kata lain analisis dilakukan terhadap pekerjaan koordinasi dan kepemimpinan terutama yang diemban oleh seorang pemimpin yang dilakukan terhadap unit-unit sebagai perwujudan pembagian kerja dilingkungannya.Perkataan pekerjaan dimaksudkan untuk menyatakan jenis-jenisnya yang berisi tugas-tugas pokok yang harus dilaksanakan para pekerja.

Menurut Handoko (Subekhi, 2012:97) "analisis pekerjaan secara sistemik menyimpulkan, mengevaluasi dan mengorganisasi informasi tentang pekerjaan-pekerjaan". Ini biasanya dilakukan oleh para spesialis yang disebut analis pekerjaan. Berdasarkan pengertian di atas dapat disimpulkan bahwa analisis jabatan adalah sebuah proses untuk menyimpulkan dan menilai informasi mengenai pekerjaan, hal ini seperti yang dikemukakan oleh Gomes (2003: 91):

Analisis pekerjaan adalah proses pengumpulan informasi mengenai suatu pekerjaan yang dilakukan oleh seorang pekerja, yang dilaksanakan dengan cara diamati atau mengadakan interview terhadap pekerja, dengan bukti-bukti yang benar dari supervisor.

Senada dengan hal itu, Hariandja (Subekhi,2012:99) mengemukakan analisis pekerjaan atau job analysis diartikan dengan :

Systematically collects, evaluate, organize information about job. These action are usually done by specialist called job analyst, who gather data about job.

(Analisis pekerjaan adalah pengumpulan, penilaian, dan penyusunan informasi secara sistematis mengenai tugas-tugas dalam organisasi, yang biasanya dilakukan oleh seorang ahli yang disebut job analyst yang mengumpulkan data mengenai pekerjaan). 
Jadi dapat dikatakan bahwa analisis jabatan adalah usaha untuk mencari tahu tentang jabatan atau pekerjaan yang berkaitan dengan tugas-tugas yang dilakukan dalam jabatan tersebut, hal ini senada dengan yang dikemukakan oleh Yoder (Subekhi, 2012:100):

Job analysis is the procedure by which the facts eith respect to each job are systematically discover and noted. It is sometimes called job study, suggesting the care with which taks, processe,responsibility, and personel requirement are investigated. Job analysis, which focuses attention on the characteristics of employees, using physical examinations tests, interviews, and other procedures for this purpose.

(Analisis pekerjaan/jabatan adalah prosedur melalui fakta-fakta yang berhubungan dengan setiap jabatan yang diperoleh dan dicatat secara sistematis. Hal ini kadang-kadang disebut dengan studi jabatan, yang mempengaruhi tugas-tugas, proses-proses, tanggung jawab, dan kebutuhan kepegawaian yang diselidiki. Analisis jabatan harus dibedakan dengan analisis pekerjaan yang menitik beratkan pada karakteristik pegawai, penggunaan ujian fisik, tes-tes, wawancara dan prosedur-prosedur lainnya untuk tujuan tersebut)

Menurut Hasibuan (Subekhi, 2012:101) “analisis pekerjaan (job analysis) perlu dilakukan agar dapat mendesain organisasi serta menetapkan uraian pekerjaan, spesifikasi pekerjaan, dan evaluasi pekerjaan". Analisis pekerjaan adalah menganalisis dan mendesain pekerjaan apa saja yang harus dikerjakan, bagaimana mengerjakannya, dan mengapa pekerjaan itu harus dilakukan. Analisis pekerjaan akan memberikan informasi mengenai uraian pekerjaan, spesifikasi pekerjaan, dan evaluasi pekerjaan bahkan dapat memperkirakan pengayaan atau perluasan pekerjaan dan penyederhanaan pekerjaan pada masa yang akan datang. Analisis pekerjaan adalah informasi tertulis mengenai pekerjaan apa saja yang harus dikerjakan dalam suatu organisasi agar tujuan tercapai.

Sedarmayanti (2011:145) mengemukakan "analisis jabatan adalah suatu proses pengumpulan informasi tentang jabatan tertentu dan penentuan unsur pokok yang diperlukan untuk menjalankan pekerjaan tertentu". Analisis jabatan merupakan proses yang sistematis dalam menentukan keterampilan, tugas, dan pengetahuan yang diperlukan untuk melakukan pekerjaan tertentu dalam organisasi. Gibson (1995:129) mengemukakan:

Analisis pekerjaan digunakan untuk meneliti kecocokan dari pekerjaan. Inilah proses mendefenisikan dan mempelajari pekerjaan dari sisi tugas dan perilaku serta menjabarkan tanggung jawab, pendidikan dan pelatihan yang dibutuhkan untuk mengerjakan pekerjaan dengan baik

\section{Analisis Beban Kerja}

Peraturan Menteri Dalam Negeri Nomor 12 tahun 2008 tentang pedoman analisis beban kerja di lingkungan Departemen Dalam negeri mngemukakan "Analisis Beban Kerja adalah suatu teknik manajemen yang dilakukan secara sistematis untuk memperoleh informasi mengenai tingkat efektivitas dan efisiensi kerja organisasi berdasarkan volume kerja". Sedangakan beban kerja adalah besaran pekerjaan yang harus dipikul oleh suatu jabatan/unit organisasi dan merupakan hasil kali antara volume kerja dan norma waktu. Menurut Komaruddin dalam kurnia (Online) "analisa beban kerja adalah proses untuk menetapkan jumlah jam kerja orang yang digunakan atau dibutuhkan untuk merampungkan suatu pekerjaan 
Marlina, Dahyar Daraba dan H. M. Said Saggaf, Analisis Kebutuhan Pegawai |21

dalam waktu tertentu". Dengan kata lain analisa beban kerja bertujuan untuk menentukan berapa jumlah personalia dan berapa jumlah tanggung jawab yang dilimpahkan kepada pegawai.

Perencanaan kebutuhan pegawai didasarkan pada hasil perhitungan beban kerja organisasi sehingga formasi pegawai yang telah disusun dapat memenuhi kebutuhan organisasi untuk pelaksanaan tugas secara profesional, efektif dan efisien. Sedarmayanti (2010:111) mengemukakan "manfaat analisis beban kerja dan tenaga kerja adalah untuk menetapkan bilangan atau jumlah karyawan yang diperluakan dalam pelaksanaan sejumlah pekerjaan tertentu selama waktu tertentu".

\section{METODE PENELITIAN}

Penelitian ini menggunakan metode deskriptif kualitatif yang bertolak dari data dan informasi. Sumber data meliputi data primer dan data sekunder dengan menggunakan Instrumen Penelitian, Fokus masalah penelitian dan Deskripsi fokus, Teknik Analisis data. Proses analisis data penelitian ini dilakukan secara terus-menerus baik dalam proses pengumpulan data maupun setelah pengumpulan data selesai dilakukan. Model analisis data tersebut digambarkan sesuai dengan Miles dan Huberman (1992: 20) dengan melakukan pengumpulan data, reduksi data, penyajian data sampai pada penarikan kesimpulan.

\section{HASIL DAN PEMBAHASAN}

Analisis kebutuhan pegawai di Sekretariat daerah Kabupaten Maros melalui beberapa tahapan yang dimulai dari tugas pokok dan fungsi, kemudian analisis jabatan, analisis beban kerja, dan selanjutnya dari analisis beban kerja akan diperoleh perhitungan kebutuhan pegawai. Tahapan tersebut dapat dilihat melalui gambar 1 di bawah ini.

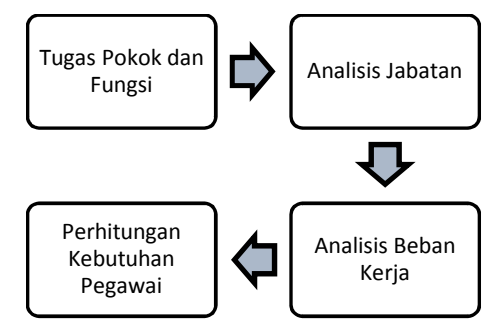

Gambar 1. Mekanisme perhitungan kebutuhan pegawai di Setda Kabupaten Maros.

Sumber: Bagian Organisasi Subbag Kelembagaan dan Analisis Jabatan

Analisis kebutuhan pegawai di Sekretariat Daerah Kabupaten Maros dimulai dari tugas pokok dan fungsi dari masing-masing pemegang jabatan yang kemudian tugas pokok dan fungsi tersebut dibuatkan analisis jabatan, dengan analisis jabatan, dapat diperoleh informasi tentang identitas jabatan, uraian jabatan dan syarat jabatan. Berangkat dari analisis jabatan 
tersebut, kemudian dibuat analisis beban kerja yang mana hasil dari analisis beban kerja tersebut dapat diketahui jumlah kebutuhan pegawai per jabatan.

Badan Kepegawaian Negara (2011), Analisis beban kerja adalah suatu teknik untuk menentukan jumlah dan jenis pekerjaan suatu organisasi yang dilakukan secara sistematis menggunakan teknis analisis jabatan dengan memperhatikan, atau teknik manajemen lainnya. Perhitungan beban kerja dengan tahapan :

- Unit pelaksana mengolah data laporan beban kerja dari satuan unit/satuan organisasi dengan menghitung isi kerjanya, dengan menggunakan rumus:

Isi kerja $=$ Beban kerja $\mathrm{X}$ Norma waktu

- Setelah seluruh jenis produk dihitung isi kerjanya, kemudian dijumlahkan untuk mencari jumlah isi kerja jabatan dan isi kerja unit dengan menggunakan satuan orang jam (OJ)

- Jam kerja efektif.

Jam kerja efektif berdasarkan Keputusan presiden nomor 68 tahun 1995 telah ditentukan jam kerja instansi pemerintah 37 jam 30 menit per minggu, baik untuk yang 5(lima) hari kerja maupun yang 6 (enam) hari kerja. MenPAN (2004) lebih lanjut menjelaskan "Jam kerja efektif adalah jumlah jam kerja formal dikurangi dengan waktu kerja yang hilang karena tidak bekerja (allowance) seperti buang air, melepas lelah, istirahat makan, dan sebagainya." Allowance diperkirakan rata-rata sekitar $30 \%$ dari jumlah jam kerja formal.

Di sekretariat daerah Kabupaten Maros menggunakan 5 (lima) hari kerja sesuai dengan keputusan Bupati Maros No 262/kpts/839/I/2014 tentang penerapan 5 hari kerja dalam seminggu bagi Pegawai Negeri Sipil Lingkup Pemerintah Kabupaten Maros yang memaparkan bahwa untuk unit kerja Sekretariat, Dinas dan Lembaga teknis daerah pemberlakuan jam kerja diuraikan sebagai berikut:

$>$ Senin s/d Kamis

○ Jam Kerja

: $07.30-16.00$

- Apel pagi

$: 07.30$

○ Jam istirahat

$: 12.00-12.15$

$\circ \quad$ Apel pulang

$: 16.00$

$>$ Hari Jumat

$\begin{array}{lll}\circ & \text { Jam kerja } & : 07.30-11.30 \\ \circ & \text { Apel pagi } & : 07.00 \\ \circ & \text { Apel pulang } & : 11.30\end{array}$
berikut:

Jam kerja efektif pada sekretariat daerah kabupaten Maros dapat dijelaskan sebagai

○ Jam kerja hari Senin sampai dengan Kamis 07.30 -16.00 dengan istirahat 15 menit $=8$ jam 15 menit/hari. 8 jam 15 menit $=495$ menit $/$ hari. 495 menit X 4 hari $=1980$ menit

- Jam kerja hari Jumat $07.30-11.30=4$ jam 30 menit $=270$ menit

○ Jadi jam kerja PNS selama seminggu $=1980$ menit +270 menit $=2250$ menit atau 7 jam 30 menit

○ Jam kerja PNS rata-rata Per Hari $=37,5$ jam : $5=7,5$ jam (7 Jam 30 Menit) 
- Jam kerja Efektif $=$ jam kerja Normal - allowance $($ jam kerja yang terbuang, di perkirakan $30 \%$ ), jadi jam kerja efektif sebanyak $75 \%$ dari jam kerja normal.

○ Jam kerja efektif Per hari $=75 \%$ X 7,5 Jam $=5$ jam 37 Menit $=337$ Menit dibulatkan menjadi 330 Menit (5 Jam 30 Menit)

○ Jam kerja efektif Per Minggu $=5$ hari X 330 Menit $=1.650$ Menit

○ Jam Kerja Efektif Per Bulan $=20$ Hari X 3.300 Menit $=6.600$ Menit

$\circ \quad$ Jam Kerja Efektif Per Bulan = 12 Bulan X 6.600 menit =79.200 Menit = 1300 jam

Setelah mengetahui jam kerja efektif, maka langkah selanjutnya adalah melakukan pengukuran beban kerja.

Tabel 1. Rekapitulasi Perbandingan Jumlah Pegawai Antara Temuan dengan Kebutuhan Berdasarkan ABK pada Setda Kabupaten Maros

\begin{tabular}{llcc}
\hline \multirow{2}{*}{ No } & & \multicolumn{2}{c}{ Jumlah Pegawai } \\
\cline { 3 - 4 } & & Teterangan & ABK \\
\hline $\mathbf{1}$ & Asisten & 4 & 3 \\
$\mathbf{2}$ & Staf ahli & 13 & 16 \\
$\mathbf{3}$ & Bagian keuangan & 23 & 25 \\
$\mathbf{4}$ & Bagian Organisasi & 12 & 12 \\
$\mathbf{5}$ & Bagian rumah tangga & 29 & 23 \\
$\mathbf{6}$ & Bagian umum & 12 & 16 \\
$\mathbf{7}$ & Bagian bina spiritual dan pemberdayaan ummat & 10 & 15 \\
$\mathbf{8}$ & Bagian ekonomi dan kesejahteraan rakyat & 13 & 14 \\
$\mathbf{9}$ & Bagian pembangunan dan program & 10 & 8 \\
$\mathbf{1 0}$ & Bagian pemberdayaan perempuan & 18 & 17 \\
$\mathbf{1 1}$ & Bagian Asset & 15 & 17 \\
$\mathbf{1 2}$ & Bagian hukum & 13 & 13 \\
$\mathbf{1 3}$ & Bagian humas & 10 & 13 \\
$\mathbf{1 4}$ & Bagian pemerintahan & 185 & 196 \\
\hline & & & \\
\hline
\end{tabular}

Sumber: Bagian organisasi setda kab. Maros

Berdasarkan jumlah kebutuhan pegawai berdasarkan ABK sebanyak 196 pegawai yang dibutuhkan sedangkan jumlah pegawai pada temuan sebanyak 185 pegawai. analisis kebutuhan pegawai di Sekretariat Daerah Kabupaten Maros menggambarkan bahwa dari segi volume dan beban tugas, tanggung jawab dan jenis pekerjaan setiap bagian unit kerja membutuhkan staff atau pelaksana pekerjaan yang berbeda jumlahnya. Dalam beberapa bagian unit kerja terdapat kesesuaian jumlah pegawai yang dibutuhkan berdasarkan analisis beban kerja dengan jumlah pegawai pada temuan. Namun, beberapa bagian unit kerja juga terdapat ketidaksesuaian.

Kebutuhan pegawai di Sekretariat Daerah Kabupaten Maros Apabila berdasarkan analisis beban kerja maka pada bagian keuangan terdapat selisih 3 pegawai dari pegawai yang ada, bagian organisasi terdapat selisish 2 pegawai, bagian bina mental dan spritual \& 
pemberdayaan umat selisih 4 pegawai, bagian ekonomi dan kesejahteraan rakyat selisih 5 pegawai, bagian pembangunan dan program selisish 1 pegawai, bagian hukum selisish 2 pegawai, bagian pemerintahan selisih 3 pegawai.

Beberapa bagian lainnya juga terdapat kelebihan pegawai dari jumlah kebutuhan pegawai berdasarkan analisis beban kerja, diantaranya: bagian umum kelebihan 6 pegawai, bagian pemberdayaan perempuan kelebihan 2 pegawai, bagian asset kelebihan 1 pegawai.

Jika melihat hasil rekapitulasi perbandingan jumlah pegawai antara temuan dengam kebutuhan pegawai berdasarkan analisis beban kerja, maka terdapat kekurangan jumlah pegawai sebanyak 11 pegawai untuk tahun 2014. Akan tetapi, jika melihat lebih dalam lagi terhadap jumlah pegawai yang ada, maka akan terlihat bahwa terdapat kesenjangan antara jumlah pegawai yang ada dengan jumlah pegawai yang dibutuhkan berdasakan ABK. Pada beberapa jabatan terdapat kekurangan pegawai dari jumlah pegawai berdasarkan ABK dan beberapa bagian lainnya terdapat kelebihan pegawai dari pegawai yang dibutuhkan berdasarkan ABK.

Melihat keadaan demikian, penulis berasumsi bahwa kesenjangan jumlah pegawai tersebut merupakan salah satu penyebab berkurangnya tingkat efektivitas kerja karena sebagian beban kerja yang banyak dikerjakan oleh sedikit pegawai, sementara disisi lain beban kerja yang sedikit memiliki banyak pegawai. Sehingga pada jam kerja efektif ada pegawai yang bekerja atau berada dalam ruangan sedang bekerja sementara beberapa pegawai yang lain berada diluar ruangan kerja dan tidak melakukan pekerjaan (dikantin, mengobrol) dan atau berada di ruangan kerja tetapi tidak melaksanakan tugas pekerjaan (memainkan permainan di komputer, chatting, facebook, dan sebagainya).

\section{PENUTUP}

Analisis kebutuhan pegawai Setda Kabupaten Maros memiliki tahapan yang dimulai dari penetapan tugas pokok, fungsi dan uraian jabatan/pekerjaan sebagai tahap awal. Tahap kedua yaitu dengan analisis jabatan, dimana dalam analisis jabatan tersebut mengandung informasi mengenai jabatan. Tahap yang ketiga yaitu setelah analisis jabatan kemudian analisis beban kerja dimana dalam analisis beban kerja tersebut diperoleh perhitungan kebutuhan pegawai untuk tiap jabatan staff. Hasil penelitian juga menunjukkan bahwa secara umum Sekretariat Daerah Kabupaten Maros jika dilihat dari Kebutuhan berdasarkan ABK masih membutuhkan pegawai sebanyak 11 pegawai dari 185 pegawai yang ada. Meskipun demikian, berdasarkan kebutuhan pegawai melalui ABK terjadi kelebihan pegawai dibeberapa bagian dan kekurangan pegawai dibeberapa bagian dalam Sekretariat Daerah Kabupaten Maros sehingga hal inimerupakan salah satu faktor yang menyebabkan tidak tercapainya efektivitas kerja pegawai karena ada beberapa pegawai yang tidak bekerja sementara ada sebagian pegawai kelebihan pekerjaan. 


\section{DAFTAR PUSTAKA}

Badan Kepegawaian Negara. 2011. Materi Analisis Jabatan Workshop Penataan dan Pemetaan dalam Rangka Pengadaan PNS Tahun 2011.

Departemen Pendidikan Nasional. 2005. Kamus Besar Bahasa Indonesia Edisi ketiga. Jakarta : Balai Pustaka.

Dessler, G. 2008. Manajemen Sumber Daya Manusia. PT Macanan Jaya Cemerlang.

Gibson, Ivancevich, \& Donnely. 1995. Organisasi (Perilaku, Struktur, Proses) edisi kedelapan jilid 1. Jakarta: Binarupa Aksara.

Gomes, F.C. 2003., Manajemen Sumber Daya Manusia. Yogyakarta : Andi.

Hasibuan, M. 2001. Pengantar Manajemen Sumber Daya Manusia. Jakarta : Haji Masagung.

Keputusan Menteri Pendayagunaan Aparatur Negara no. Kep/75/M.PAN/7/2004.

Kurnia, A. 2013. Defenisi Analisis Beban Kerja (Online), (wordpress.com, Diakses 11 Maret 2014 pukul 23.19 Wita).

Manullang, M. 2006. Manajemen Personalia. Yogyakarta : Gadjah Mada University Press.

Martoyo, S. 2000. Manajemen Sumber Daya Manusia. Yogyakarta: BPFE.

Miles, M.B., \& Haberman.1994. Qualitative Data Analysis, an Expanded Sourcebook (ed.2). newbury Park. CA : Sage.

Muzawwir, A. 2008. Analisis kebijakan pemekaran Wilayah kabupaten Batubara dalam Perspektif peraturan pemerintah no 129 2000. Tesis Program Studi pembangunan Universitas Samudra Utara.

Nawawi, H. 2008. Perencanaan SDM Untuk Organisasi Profit yang Kompetitif. Yogyakarta: Gadjah Mada University Press

Ndaraha, T. 2002. Pengantar Teori Pembangunan Sumber Daya Manusia. Jakarta: Rineka Cipta.

Peraturan Menteri dalam Negeri Nomor 12 Tahun 2008 Tentang Pedoman Analisis Beban Kerja Di Lingkungan Departemen Dalam Negeri(Online),(fp.ub.ac.id, diakses 11 Maret 2014 pukul 20.29 Wita).

Peraturan Menteri PAN \& Reformasi Birokrasi Nomor 26 Tahun 2011 Tentang Pedoman Perhitungan Jumlah PNS Untuk Daerah.

Rivai, V. 2003. Kepemimpinan dan perilaku Organisasi edisi Kedua. Jakarta : PT Rajagrafindo Persada.

Salim, E. 2006. Aspek Sikap Mental Dalam Manajemen Sumber Daya Manusia. Bogor : Ghalia indonesia. 
26| Ad'ministrare, Vol. 2 No. 1, 2015

Samsuddin, S. 2006. Manajemen Sumber Daya Manusia. Bandung : Pustaka Setia.

Sedarmayanti. 2011. Manajemen Sumber Daya Manusia (Reformasi Birokrasi Dan Manajemen Pegawai Negeri Sipil. Bandung : PT Refika Aditama.

Siswanto. 2011. Pengantar Manajemen. Jakarta: Bumi Aksara.

Subekhi, A \& Jauhar, M. 2012. Pengantar Manajemen Sumber Daya Manusia (MSDM). Jakarta : Prestasi Pustakaraya.

Sugiyono. 2013. Metode Penelitian Kuantitatif Kualitatif dan R\&D. Bandung : Alfabeta.

Surrachmad. 1980. Metode Penelitian. Bandung : Ganesha.

Yuniarsih \& Suwanto. 2008. Manajemen Sumber Daya Manusia (Teori, Aplikasi dan Isu Penelitian). Bandung : Alfabeta. 